Spirkova, D., Kloudova, J., Kljucnikov, A., Stehlikova, B. (2019). Economy of Heating and Competitiveness of the State - The Link between the Life Expectancy and the Heating Fuel Type. The Case of the Slovak Republic. Journal of Competitiveness, 11(1), 116-134. https://doi.org/10.7441/ joc. 2019.01 .08

\title{
ECONOMY OF HEATING AND COMPETITIVENESS OF THE STATE - THE LINK BETWEEN THE LIFE EXPECTANCY AND THE HEATING FUEL TYPE. THE CASE OF THE SLOVAK REPUBLIC
}

- Daniela Spirkova, Jitka Kloudova, Aleksandr Kljucnikov, Beata Steblikova

\begin{abstract}
Protecting the environment and maintaining the EU's competitiveness must be inextricably linked. From this perspective, the scope of present article may be seen as quite timely. Air pollution is the main environmental risk factor contributing to deterioration of the health of the population, and consequently influences the economic development of the state. The usage of hard fuels for the heating of local dwellings is one of the most important sources of local air pollution. The aim of this paper is to identify the relationship between the pollution caused by heating and the health of the population. The health status of the population was assessed using the potential years of life lost per 100,000 inhabitants. Data on the energy sources used for heating were taken from a survey of all dwellings in the Slovak Republic from the 2011 census of inhabitants, homes and apartments. To create clusters of similar municipalities in terms of the variables considered, we used the fuzzy cluster analysis for individual size-standard groups of municipalities. The map view of the fuzzy cluster analysis results confirmed the division of the Slovak Republic into two regions - the north, which showed more favorable results and the south, which showed negative findings. The membership function values of the first cluster indicate a significant positive spatial autocorrelation as measured by Moran's coefficient. A local Moran cluster map identified the areas of interest investigated below.
\end{abstract}

Keywords: heating, solid fuel, gas heating, PYLL, health, Slovak Republic JEL Classification: O18, 013, 115

Received: September, 2018

1st Revision: January, 2019

Accepted: February, 2019

\section{INTRODUCTION}

The 7th EU Global Environmental Action Programme to 2020 sets out a long-term environmental strategy designed to be sufficiently flexible and responsive to future challenges and the increasing associated systemic risks. As set forth by the EC, the 7th EAP sets out an overall 
approach aimed at achieving an environmentally friendly and competitive economy that will protect our natural resources and health for present and future generations.

Lindsay et al. (2011) have described climate change as the world's greatest health threat in the 21st century. Stabilizing the global climate will require a significant reduction in greenhouse gas emissions, and the manner of these cuts will be key for human health. The effects may be negative (e.g. food shortages resulting from biofuels replacing food crops) or positive (e.g. fewer ailments caused by air pollution if the energy production moves from coal to cleaner technologies). According to Kolková (2018a) and Brożyna et al. (2016) proper forecasting can be a fundamental source of competitive advantage. According to Hessel et al. (1997), despite consistent evidence for adverse respiratory and cardiovascular health effects related to particulate air pollution, significant gaps remain in knowledge of the mechanisms whereby particulate air pollution affects human health. Although significant unanswered questions persist regarding the effects of particulate air pollution, the information available suggests that such air pollution at a level corresponding to current standards can be associated with measurable negative health effects.

According to Adlong \& Dietsch (2015), the likelihood of climate change having adverse effects on health is high. The mitigation of health impacts and health risks resulting from climate change is reinforced by climate call-to-action programmes that seek to implement cleaner energy production as well as other initiatives to reduce greenhouse gas emissions. Climate change needs to be seen both as an environmental and health problem.

Recent years have seen significant steps taken in analyzing environmental damage, notably the Extern-E project (European Commission, 2018). Such research results provide significant evidence that typical air pollutants (NOx and SOx particles) from fossil fuels constitute significant public health costs comparable to the costs of global warming caused by $\mathrm{CO} 2$ emissions. Total external costs for natural gas are relatively low, but much higher for coal and lignite. Conversely, the external costs of nuclear, wind and photovoltaic energy are very low. External water costs vary extremely from place to place, while biomass strongly depends on specific applied technologies and can be quite high. According to Marchetti et al. (2019), biomass combustion significantly contributes to indoor and outdoor air pollution and to the adverse health effects observed in the exposed populations. According to Frasca et al. (2018), biomass-fueled heating systems are a significant source of indoor pollution, mainly due to the cleaning operations required for the removal of residual ash which release particles in both the fine and the coarse size range. Paolotti et al. (2017) have put forth an economic and environmental assessment of forest biomass in terms of heating. In their conclusion, a number of improvements have been proposed both in terms of the economic competitiveness of the agro-energy supply chains considered as well as reducing their environmental impact.

Many toxic pollutants to which we are exposed are associated with combustion (Kinney et al., 2015). In recent years, more scientific studies have confirmed that long- and short-term exposure to solid pollutants leads to adverse effects on health. As proposed by Borrego et al. (2008), smoke from fuel, urban air pollution, and dust particles at the workplace contribute to an increased disability-adjusted life year (i.e. DALY, whereby one DALY represents the loss of one full year of health). According to Wilkinson et al. (2009), the energy used in dwellings is an important target for steps to avert climate change, whereby properly designed and implemented interventions could provide major co-benefits for public health. 
Markandya \& Wilkinson (2007) claim that electricity provision has been a great advantage to society, yet has both health benefits as well as costs - health burdens are appreciably smaller for electricity generation from natural gas, and lower still for nuclear power. A comparison of various forms of commercial power generation via fuel cycle methods developed in European studies shows the health burdens to be highest for power stations that most heavily pollute the atmosphere (i.e. those based on lignite, coal, and oil). The health burdens are appreciably smaller for electricity generation from natural gas, and lower still for nuclear power. This same ranking also applies in terms of greenhouse gas emissions and thus, potentially, to the long-term health, social, and economic effects arising from climate change. Nevertheless, nuclear power remains controversial because of public concern about nuclear waste storage and the risk of catastrophic accident. The negative health effects of electricity generation from renewable sources have not been assessed as fully as those from conventional sources, yet for solar, wind, and wave power such effects would seem minor; while those of biofuels depend on a fuel type and a combustion method.

According to Finkelman \& Gross (2009), coal is one of the most important sources of energy and will remain the dominant energy source in developed and developing countries at least for the first half of the 21st century. Environmental issues related to coal - its extraction, storage, and combustion - are associated with potential environmental problems and human health. The explorative case study by Frantal \& Novakova (2014) attempts to identify significant associations between the spatially uneven distribution of coal power plants, and the environmental and socioeconomic characteristics and development trends of affected areas (Androniceanu \& Popescu, 2017).

Brown coal has been the main energy source for the Czech economy for more than 150 years, but its role in coming decades is now a source of heated debate. Damages of up EUR 7 billion between 2015 and 2050 will arise from the use of coal for the production of electricity and heat, and most of the impact will be borne by populations outside the Czech Republic, as stated by Maca \& Melichar (2016). Cooper (1980) underlines that there is a significant environmental impact from domestic wood burning emissions, and air pollution from this source is widespread and growing.

In the study by Jandačka et al. (2015), pure brown coal, i.e. without additional municipal waste components, was considered as a source of energy for heating. Their results show that about one-quarter more $\mathrm{CO} 2$ is produced in the combustion of natural gas. The other pollutants measured were found to be $200-300 \%$ higher in burning brown coal than other sources. Natural gas combustion produces negligible amounts of sulphur, mercury and particulates. Nitrogen oxides (NOx), which are smog precursors, are found in the combustion of natural gas, as shown by Alvarez et al. (2012).

Dechezleprêtre \& Sato (2017) have reviewed the empirical literature on the impacts of environmental regulations on firm competitiveness as measured by trade, industry location, employment, productivity and innovation (Androniceanu \& Drăgulănescu, 2016). As measures to address competitiveness impacts are increasingly incorporated into the design of environmental regulations, future research will be needed to assess the validity and effectiveness of such measures as well as to ensure they are compatible with the environmental objectives of the policies. 
Marikina (2018) describes the impact that ecological regulations and management have on the national competitiveness in the Balkan states, i.e. that increasing regulation along with the development of ecological sustainability will lead to higher competitiveness in Albania, Bulgaria, Greece, Romania, Croatia and Serbia. By estimating a simultaneous panel data model of environmental innovation and toxic air pollution, Carrión-Flores \& Innes (2010) have identified bi-directional causal links between the two. Considering the effects of household-fuel use on PM2.5 exposures, Zhao et al. (2018) recommend that this factor be more highly prioritized in national control policies.

An overview of pollutants and emissions in the EU is detailed by Eurostat. In the Global Household Air Pollution (HAP) Measurements database commissioned by the World Health Organization, an organized summary of data reported in the literature describing HAP microenvironments, methods and measurements is provided (Shupler et al., 2018). As of June 2018, the database contains measurements from 43 countries obtained from 196 studies published through 2016. The database includes information useful for understanding the range of household and personal air pollution measurements that have been collected in a country, as well as characteristics of the cooking environment, including primary cooking fuel type, stove type, heating fuel type and kitchen location.

According to Eurostat (2018), SOx was the most polluting substance with the largest emission reduction in the EU-28. SOx emissions in 2015 amounted to 2.8 million tonnes compared to 25.3 million tonnes in 1990. SOx emissions have mostly been reduced in the energy production and distribution sector. $\mathrm{SOx}$ reductions resulted from a combination of policy measures: switching fuel source in energy-related sectors from solid and liquid fuels with high sulphur content to low sulphur fuels such as natural gas; and the use of flue gas desulphurisation (FGD) techniques in industrial installations.

Over the last 26 years, NOx emissions across the EU have fallen from 17.6 to 7.8 million tonnes. The largest reduction was made in road transport - the main sector contributing to total NOx emissions - which primarily resulted from the installation of catalytic converters into vehicles. NOx emissions in the energy production and distribution sector have also been reduced thanks to the introduction of specific emission reduction technologies and the transition from solid to gaseous fuels. NH3 emissions derive almost entirely from agriculture. Compared to other pollutants, the NH3 emission reduction was average. In the EU-28, NH3 emissions have fallen from 5.2 to 4.0 million tonnes over the last 26 years. Major reductions have been achieved by better management of manure.

Between 1990 and 2015, NMVOC emissions across the EU decreased from 17.1 to 6.6 million tonnes. A large decrease was recorded in the road transport sector. PM2.5 emissions have fallen by around a quarter between 2000 and 2015 across the EU. The most significant reductions have been made in the energy production and distribution sector, as well as the road transport.

The quality of environment also affects tourism. Atilla-Tóth (2016) focuses on a complex question from the perspective of the hotel industry. It tries to draw attention to the importance of hotels, enhancing it on the basis of the tourism destination competitiveness models and introducing the role and place of the hotel industry in the most important models. 
The paper aims to identify the relationship between the energy sources used for heating and potential years of life lost (PYLL) in the Slovak Republic at the NUTS 5 level (towns and municipalities).

\section{MATERIALS AND METHODS}

Data on energy sources used for heating come from the Population and Housing Census in 2011 (The Statistical Office of the Slovak Republic, 2013, further referred to as “SOSR”). Data on potential years of life lost per 100,000 of the population (PYLL100) come from the State Geological Institute of Dionyz Stur (2018), further referred to as "SGIDS". The concept of years of potential life lost (YPLL) or potential years of life lost (PYLL) involves estimating the average time a person would have lived had he or she not died prematurely (Gardner \& Sanborn, 1990). This measure is used to help quantify social and economic loss owing to premature death, and has been promoted to emphasize specific causes of death that affect younger age groups (Gardner \& Sanborn, 1990).

PYLL inherently incorporates age at death, and its calculation mathematically weights total deaths by applying values to death at each age. In this paper, we will denote potential years of life lost per 100,000 inhabitants as PYLL100. Energy sources used for heating were in the Population and Housing Census in 2011 divided into gas, electricity, liquid fuels, solid fuels, other fuels, and no fuels. The spatial distribution of dwellings in terms of energy sources used for heating can be described as follows. Gas is used for heating dominantly in the Western and South-Eastern part of Slovakia. On the opposite, solid fuel is used for heating mostly in the Central and North-Eastern part of the country. Dwellings without heating are almost evenly distributed over the country.

The relationship between variables can vary in intensity, from total independence to complete dependence. The correlation coefficient $r$ determines the degree of linear dependence (Wherry, 2014).

The spatial distribution of PYLL100, the share of dwellings by sources of energy used for heating (gas, solid fuel, without heating), was evaluated using the Moran's coefficient I. The Moran's I is a correlation coefficient that measures the overall spatial autocorrelation of a data set. A positive value for I indicates that the feature is surrounded by features with similar values. The significance of the Moran's coefficient was tested using the Monte Carlo simulations (9999 permutations). The Local Moran statistic identifies local clusters and spatial outliers. The cluster or outlier type field distinguishes between a statistically significant cluster of high values $(\mathrm{HH})$, a cluster of low values (LL), an outlier in which a high value is surrounded primarily by low values (HL), and an outlier in which a low value is surrounded primarily by high values (LH). Local Moran's I identifies concentrations of high values, concentrations of low values, and spatial outliers (ArcGIS Pro, 2018, Chun \& Griffith, 2013, Kolková, 2018b).

We used the fuzzy cluster analysis to generate clusters of similar municipalities (Kacprzyk \& Piedrczyk, 2015). Fuzzy clustering generalizes partition clustering methods. The fuzzy c-means clustering performs clustering by iteratively searching for a set of fuzzy clusters and the associated cluster centres that represent the structure of the data as best as possible. The Geoda software was used for the calculations. 


\section{RESULTS AND DISCUSSION}

According to the World Health Organization, air pollution is a major environmental risk factor that contributes to worsened public health. In Slovakia, 58,400 PYLL are attributed to PM2.5 exposure, 1,200 to NO2 exposure, and 1,800 to O3 exposure. So in the case of 100,000 inhabitants, 1,077 PYLL100 for PM2.5 exposure, 21 PYLL100 for NO2 exposure, and 34 PYLL for O3 exposure. In the EU-28, the PYLL attributed to PM2.5, NO2 and O3 exposure are 4,278,800, 798,500 and 145,200 , respectively.

The assessment of the Slovak population's health status by means of the fuzzy cluster analysis was carried out for the PYLL100 health indicator, and the proportion of dwellings by the energy source used for heating in 2,870 municipalities. Of the total 2,883 municipalities in Slovakia, all four military districts (Javorina, Lešt', Valaškovce and Zahorie) were excluded from statistical data processing.

In the next step of processing the input data for the fuzzy cluster analysis, we divided the municipalities according to population size into the standard size groups commonly used in demographics. The number of municipalities according to the size category (in 2011) in the SR is 1-199 (365), 200-499 (804), 500-999 (785), 1,000-1,999 (547), 2,000-4,999 (253), 5,000- 9,999 (53), 10,000-19,999 (32), 20,000-49,999 (29), 50,000-99,999 (9), and 100,000 or more (2).

On the date of the Population and Housing Census in 2011, according to the Statistical Office of the SR, there were 1,994,897 dwellings in the Slovak Republic, of which 1,776,698 (i.e. 89.1\%) were inhabited. In that census, energy sources used for heating were divided into gas $(61.5 \%$ of dwellings), electricity (3.3\% of dwellings), liquid fuel (1.2\% of dwellings), solid fuel ( $16 \%$ of dwellings), other fuels (3.3\% of dwellings), and no heating (1.5\% of dwellings).

In the analysis, we have included the share of dwellings heated by gas, solid fuel, and without heating. Dwellings heated by gas and solid fuel represent $89.25 \%$ of the total number of occupied dwellings. Dwellings without heating represent only $1.72 \%$, but are inhabited by low-income population who can be expected to have worse state of health as well as self-care. Results of the correlation analysis confirm the choice of energy sources. All three Pearson correlation coefficients between PYLL100 and the proportion of dwellings heated by gas, solid fuel and without heating are significant (Table 1). Other correlation coefficients are not significant (their P-value is greater than 0.05).

Tab. 1 - Pearson correlation coefficient between PYLL100 and the proportion of dwellings by energy. Source: Own processing, data SGIDS \& SOSR, 2018

\begin{tabular}{|l|l|l|l|l|l|l|}
\hline & gas & electricity & liquid & solid fuel & other & $\begin{array}{l}\text { without } \\
\text { heating }\end{array}$ \\
\hline $\begin{array}{l}\text { Correlation } \\
\text { coefficient }\end{array}$ & -0.180 & -0.014 & -0.013 & 0,187 & -0.026 & 0.113 \\
\hline P-value & 0.0000 & 0.4590 & 0.4917 & 0.0000 & 0.1690 & 0.0000 \\
\hline
\end{tabular}

All four evaluated indicators show statistically a significant spatial autocorrelation based on the P- values of Moran's coefficient I (Table 2). 
Tab. 2 - Testing spatial autocorrelation. Source: Own processing, data SGIDS \& SOSR, 2018

\begin{tabular}{|l|l|l|}
\hline Indicator & Value of Moran's coefficient I & P-value \\
\hline Share of dwellings heated by gas & 0.5513 & 0.001 \\
\hline Share of dwellings heated by solid fuel & 0.5571 & 0.001 \\
\hline Share of dwellings without heating & 0.0639 & 0.002 \\
\hline PYLL100 & 0.0875 & 0.001 \\
\hline
\end{tabular}

Since Moran's coefficients were significant for all four evaluated indicators, we were interested in local Morans coefficients.

The primary cause of contemporary air pollution is particularly emissions from the heating of dwellings and transport emissions, as well as high background concentrations, i.e. pollution where the emission source cannot be directly determined. Current analyses suggest that local emissions from local heating and transport contribute to air pollution more than emissions from industry. But industrial emissions are also not disappearing - they can contribute to increased regional background values. Given that different emission sources vary for individual size types of municipalities, we have performed the fuzzy c-cluster analysis with two clusters for each size type of municipality separately.

For individual size groups of municipalities, we have created two basic clusters for the data described: from the perspective of the PYLL100 health indicator, and a set of indicators characterizing energy sources used for heating. The value of membership function to fuzzy set can be freely interpreted as a measure according to which the given territory belongs to a cluster of similar territories from the perspective of the indicators used. The value of membership function $\mathrm{Ax}$ into the first cluster and Bx member function into the second cluster is marked. For each territorial unit (municipality), we have calculated the value of the membership function in individual clusters $\mathrm{Ax}$ and $\mathrm{Bx}$. From the theory we know that in this special case, $\mathrm{Bx}=1-\mathrm{Ax}$. Therefore, it is sufficient to consider the values Ax for inclusion of the municipality into particular clusters. The mode of inclusion is depicted in Figure 1.

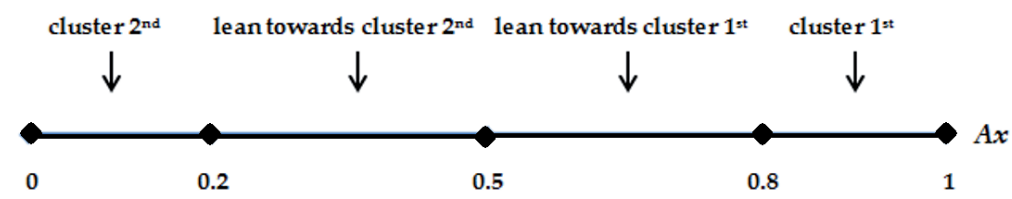

Fig. 1 - The mode of inclusion. Source: Own visualization

The first "bad" cluster includes all municipalities with a membership function value Ax of at least 0.80 . The second "good" cluster includes all municipalities with a membership function value $\mathrm{Bx}$ of at least 0.80 .

We identify the centroid of the cluster as a typical representative of these territories. We attach the attribute "good" to the cluster for which a value of PYLL is lower, and vice versa, the at- 
tribute "bad" to the cluster with a higher PYLL value of a typical representative. We assume that this distribution of the health status of inhabitants of given municipalities measured by PYLL to some extent also reflects the environmental quality or air pollution.

Tab. 3 - The percentage share of centroid indicators of the first cluster ("bad") compared to the values for the second cluster ("good"). Source: Own processing, data SGIDS \& SOSR, 2018

\begin{tabular}{|c|c|c|c|c|c|c|c|c|c|c|c|c|}
\hline \multirow{3}{*}{ 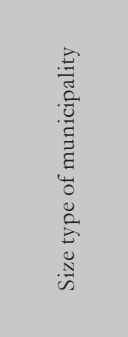 } & \multicolumn{4}{|c|}{ Cluster 1} & \multicolumn{4}{|c|}{ Cluster 2} & \multicolumn{4}{|c|}{ Shere Cluster $1 /$ Cluster 2} \\
\hline & \multicolumn{3}{|c|}{ heating energy source } & & \multicolumn{3}{|c|}{ heating energy source } & \multirow[b]{2}{*}{ 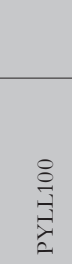 } & \multicolumn{3}{|c|}{ heating energy source } & \multirow[b]{2}{*}{$\begin{array}{l}8 \\
\vdots \\
\overline{1}\end{array}$} \\
\hline & gas & $\begin{array}{l}\text { solid } \\
\text { fuel }\end{array}$ & $\begin{array}{l}\text { with- } \\
\text { out } \\
\text { heat- } \\
\text { ing }\end{array}$ & $\begin{array}{l}8 \\
\vdots \\
= \\
\vdots \\
=\end{array}$ & gas & $\begin{array}{l}\text { solid } \\
\text { fuel }\end{array}$ & $\begin{array}{l}\text { with- } \\
\text { out } \\
\text { heat- } \\
\text { ing }\end{array}$ & & gas & $\begin{array}{l}\text { solid } \\
\text { fuel }\end{array}$ & $\begin{array}{l}\text { with- } \\
\text { out } \\
\text { heat- } \\
\text { ing }\end{array}$ & \\
\hline $1-199$ & $10.8 \%$ & $79.8 \%$ & $3.6 \%$ & 10499 & $24.2 \%$ & $67.5 \%$ & $1.6 \%$ & 3112 & 0.45 & 1.18 & 2.32 & 3.37 \\
\hline $200-499$ & $34.1 \%$ & $58.3 \%$ & $1.5 \%$ & 7612 & $47.4 \%$ & $45.8 \%$ & $0.8 \%$ & 3425 & 0.72 & 1.27 & 1.82 & 2.22 \\
\hline $500-999$ & $54.3 \%$ & $39.2 \%$ & $1.3 \%$ & 6276 & $58.6 \%$ & $34.9 \%$ & $0.9 \%$ & 3397 & 0.93 & 1.12 & 1.44 & 1.85 \\
\hline $1000-1999$ & $61.8 \%$ & $32.1 \%$ & $0.9 \%$ & 5579 & $69.8 \%$ & $24.3 \%$ & $0.8 \%$ & 3464 & 0.88 & 1.32 & 1.21 & 1.61 \\
\hline $2000-4999$ & $62.7 \%$ & $30.3 \%$ & $1.2 \%$ & 5445 & $75.9 \%$ & $19.3 \%$ & $0.8 \%$ & 3648 & 0.83 & 1.57 & 1.46 & 1.49 \\
\hline $5000-9999$ & $74.2 \%$ & $18.4 \%$ & $0.9 \%$ & 4794 & $78.8 \%$ & $12.8 \%$ & $0.7 \%$ & 3639 & 0.94 & 1.43 & 1.40 & 1.32 \\
\hline $\begin{array}{l}10000 \\
-19999\end{array}$ & $81.3 \%$ & $9.5 \%$ & $1.1 \%$ & 4365 & $75.1 \%$ & $11.2 \%$ & $1.2 \%$ & 3700 & 1.08 & 0.84 & 0.91 & 1.18 \\
\hline $\begin{array}{l}20000 \\
-49999\end{array}$ & $86.7 \%$ & $5.0 \%$ & $1.8 \%$ & 4290 & $77.6 \%$ & $9.8 \%$ & $1.6 \%$ & 3424 & 1.12 & 0.51 & 1.15 & 1.25 \\
\hline $50000+$ & $71.7 \%$ & $6.6 \%$ & $3.1 \%$ & 3626 & $66.5 \%$ & $12.9 \%$ & $2.6 \%$ & 3098 & 1.08 & 0.52 & 1.19 & 1.17 \\
\hline
\end{tabular}

Gas is considered an ecological fuel despite also contributing to the greenhouse effect. As gas contains mainly methane, it has the smallest share of $\mathrm{CO} 2$ per unit of energy released during combustion compared to other fossil fuels.

The spatial distribution of dwellings heated by gas does not follow the SPP distribution network (SPP, 2018). A higher share of gas-heated dwellings is near the capital city Bratislava, in Western Slovakia, parts of Eastern Slovakia, and North-Eastern Slovakia. There are about 700 smaller municipalities without gas in Slovakia today, mostly in the mountainous areas. SPP - the national gas supplier - is not interested in supplying gas to such municipalities due to the high costs involved, and the interest of self-governing regions has also abated due to recent high gas prices.

In terms of municipality size, the proportion of dwellings heated by gas is increasing for typical representatives of both clusters. It is higher for the second (good) cluster from the size 1-199 up to 5,000-9,999. For municipality size from 10,000-19,999 to 50,000+, the proportion of dwellings heated by solid fuel is higher for the first (bad) cluster. However, the differences are small.

Coal combustion, despite modern technology, is one of the largest air pollutants. Substances released into the atmosphere mainly comprise $\mathrm{CO} 2$ emissions, mercury $(\mathrm{Hg})$, nitrogen oxides (NOx), and sulphur oxides (SOx). In terms of health impacts, the two most serious emissions 
are fine dust particles (PM) and ground-level ozone. Dust particles are the sum of various size particles freely dispersed into the air (Dančova, 2018). Wood heating, which is classified as a renewable source, has a long tradition in Slovakia and is one of the cheapest forms. However, due to its negative environmental impact, heat sources for wood combustion are subject to strict limits in the EU.

In some EU countries (e.g. Germany, Austria), it is virtually impossible to use a traditional solid fuel boiler (Plus, 2018). Solid fuel heating has the common additional problem that low-income population groups often burn municipal waste - which dramatically escalates the production of harmful emissions - to cut costs (Jandacka et al., 2015; Omelchuk, 2018; Volchik et al. 2018). Dwellings heated by solid fuel are predominant in Central Slovakia and the north of Eastern Slovakia. In terms of size of municipalities, the share of dwellings heated by solid fuels is decreasing for typical representatives of both clusters. It is lower for the second (good) cluster from the size 1-199 up to 5,000-9,999. The biggest difference is for 1-199. For municipalities from 10,000-19,999 to 50,000+, the share of dwellings heated by solid fuel is higher for the second (good) cluster. In these municipalities, which are often cities, traffic is the main contributor to air pollution.

Although dwellings without heating are almost evenly dispersed throughout Slovakia, there are contiguous islands of municipalities with very few dwellings of this type. The share of unheated dwellings is higher in the first cluster ("bad") than in the second cluster for all municipalities except for 10,000-19,999. The share of dwellings without heating has a U-shape trend - it decreases from 1-199 to 2,000-4,999 and then increases. PYLL100 values of typical representatives of clusters according to the size categories of municipalities are presented in Figure 2.

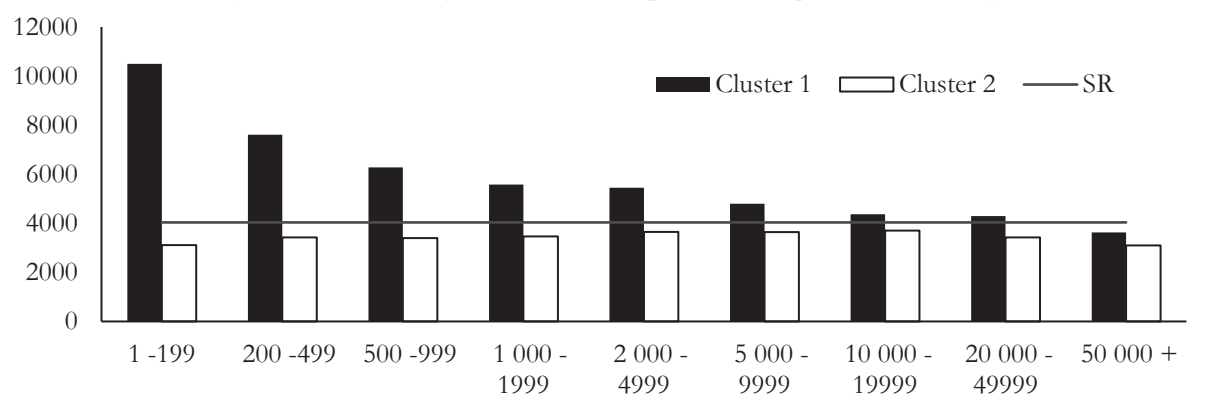

Fig. 2 - PYLL100 values of typical representatives of clusters according to the size categories of municipalities. Source: Own processing, data SGIDS \& SOSR, 2018

The values of a typical representative of the cluster with higher PYLL100 values are, except for the size type 50,000+, above the average PYLL100 SR (4,033 years). The values of a typical representative of the cluster with good PYLL100 values are under the PYLL100 SR value but close to it. The difference between the PYLL100 of typical representatives of clusters decreases as the size of the municipality grows. 


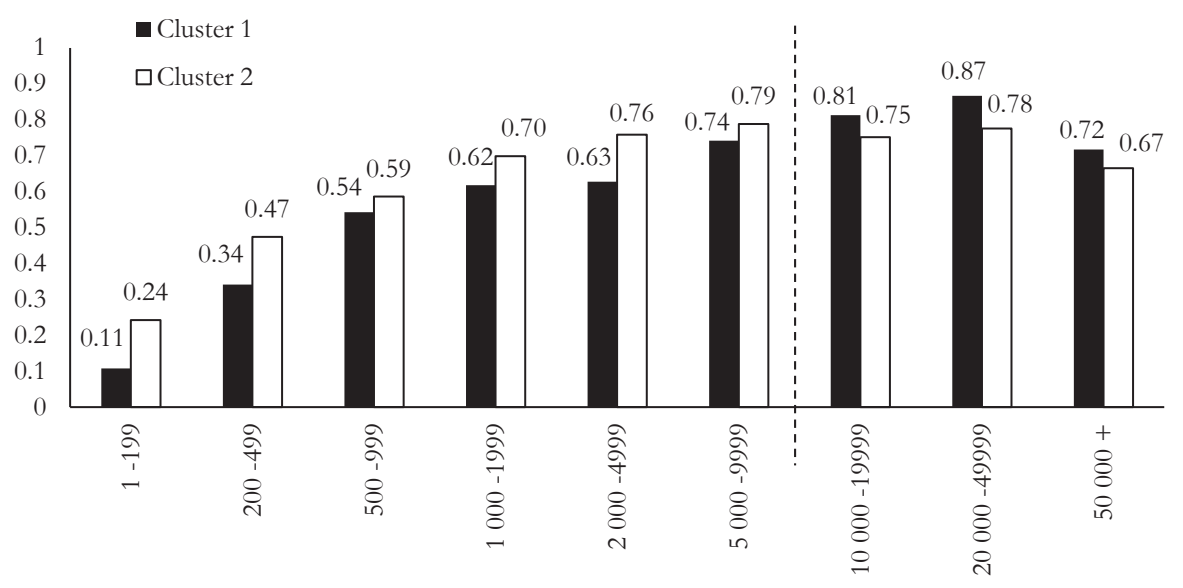

Fig. 3 - Share of gas heating dwellings in individual clusters according to the size type of municipality. Source: Own processing, data SGIDS \& SOSR, 2018

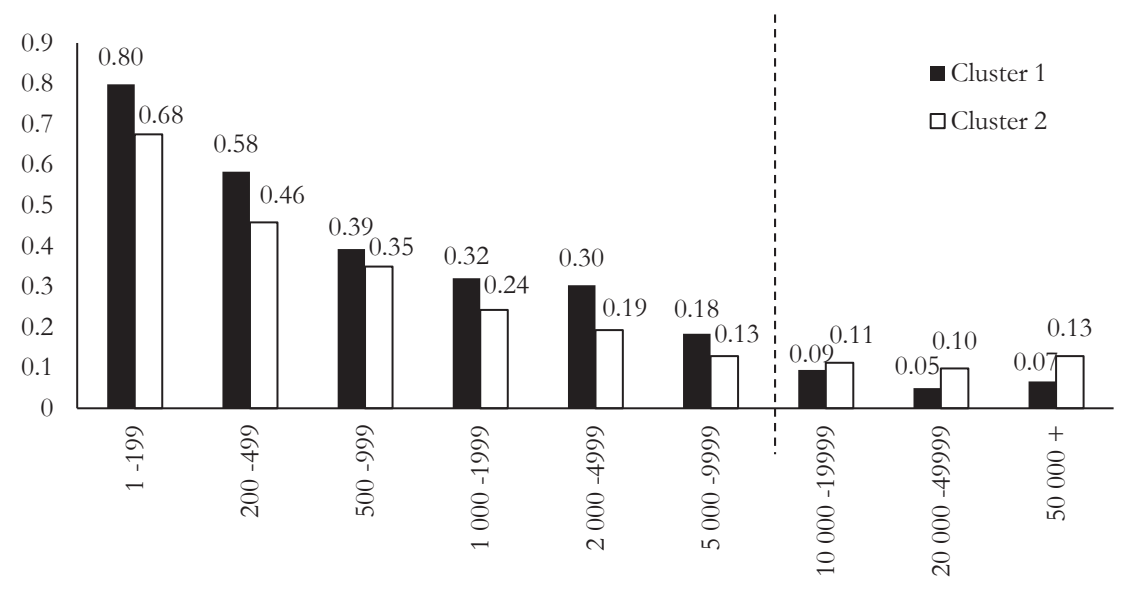

Fig. 4 - Share of solid fuel heating dwellings in individual clusters according to the size type of municipality. Source: Own processing, data SGIDS \& SOSR, 2018 


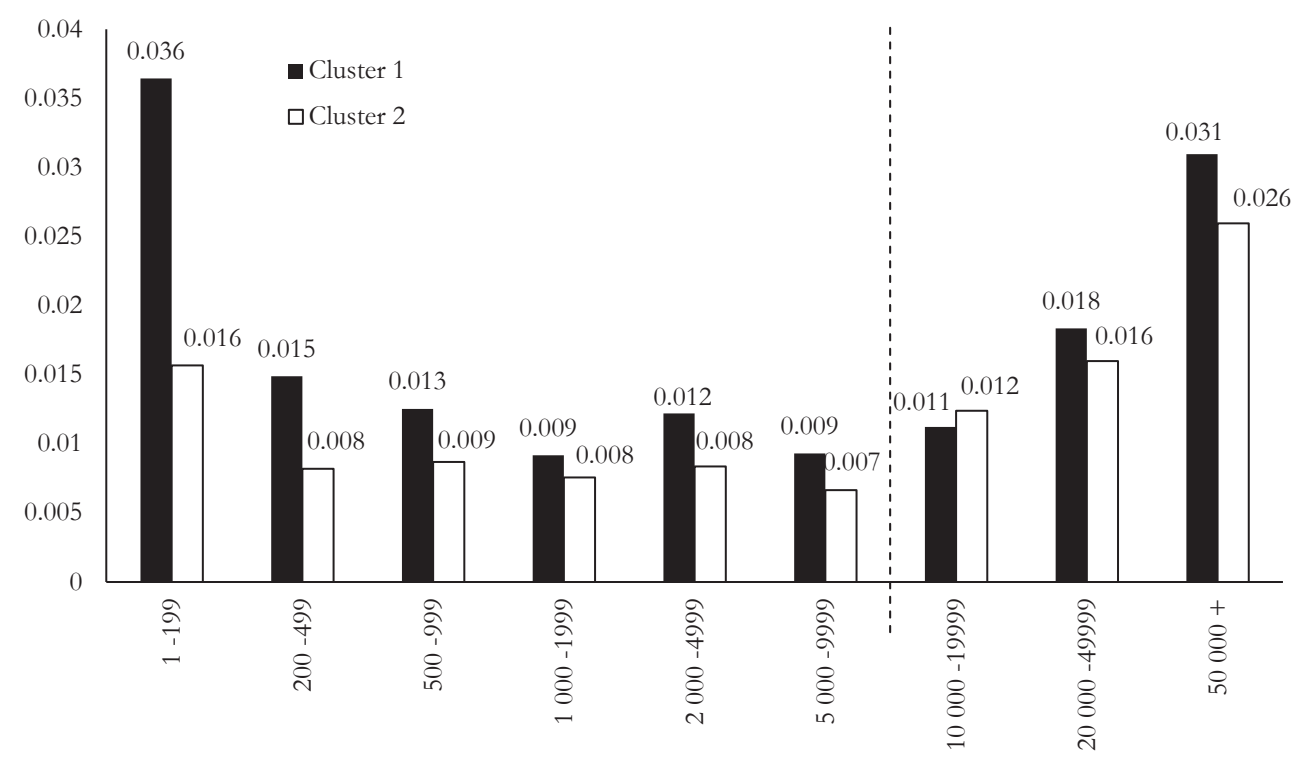

Fig. 5 - Share of dwellings without heating in individual clusters according to the size type of municipality. Source: Own processing, data SGIDS \& SOSR, 2018

In the case of the smallest municipalities of size 1-199, the share of dwellings heated by gas is predominant. The PYLL100 value $(10,499)$ of a typical representative of the first cluster, with

a predominant share of dwellings heated by solid fuel, is several times higher than the PYLL100 value in the SR - 4,033 years. The first cluster also includes municipalities with a higher share of dwellings without any heating at all. PYLL100 (3,112 years) of a typical representative of the second cluster is lower than the PYLL of the Slovak Republic. This includes small municipalities with sufficient resources for gas installation, and an almost negligible share of dwellings without heating.

In all municipalities up to 9,999 inhabitants, a typical representative of a good cluster has

a higher share of dwellings heated by gas than dwellings heated by solid fuels, while the opposite holds true for municipalities with 10,000+ inhabitants. A typical representative of a good cluster has a lower share of dwellings heated by gas than a typical representative of a bad cluster, although the differences are small. In cities, traffic contributes to air pollution much more than heating energy sources.

A map view of results of the fuzzy c-cluster analysis is presented in Figure 6. The results confirm the division of the SR into a "better" north and "worse" south. 


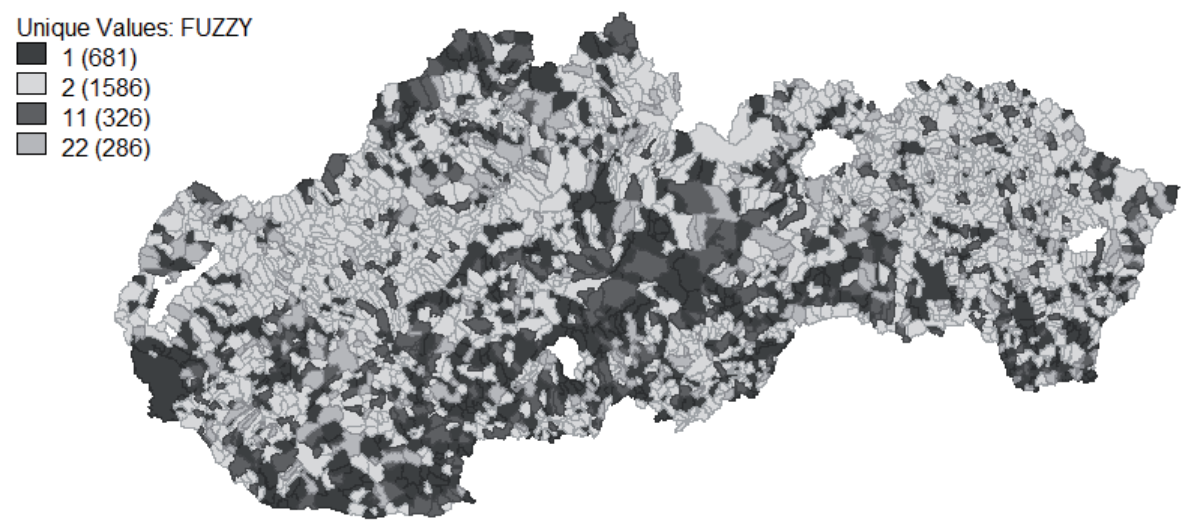

Fig. 6-Map with results of the fuzzy c-cluster analysis. Source: Own processing, data SGIDS \& SOSR, 2018

Note: 1 - cluster 1,2 - cluster 2, 11 - lean toward cluster 1, 22 - lean toward cluster 2

The affiliation of municipalities and their inhabitants within individual size groups to individual definite and non-definite clusters is summarized in Tables 4 and 5.

Tab. 4 - The affiliation of municipalities and their inhabitants within individual size groups to clusters (number). Source: Own processing, data SGIDS \& SOSR, 2018

\begin{tabular}{|l|l|l|l|l|l|l|l|l|}
\hline \multirow{2}{*}{$\begin{array}{l}\text { Size type of } \\
\text { municipality }\end{array}$} & \multicolumn{2}{|l|}{ Cluster 1} & \multicolumn{2}{l}{$\begin{array}{l}\text { Lean toward to } \\
\text { cluster } 1\end{array}$} & \multicolumn{2}{l}{$\begin{array}{l}\text { Lean toward to } \\
\text { cluster 2 }\end{array}$} & \multicolumn{2}{l|}{ Cluster 2 } \\
\cline { 2 - 10 } & $\begin{array}{l}\text { Number } \\
\text { ants }\end{array}$ & $\begin{array}{l}\text { Number } \\
\text { of munici- } \\
\text { palities }\end{array}$ & $\begin{array}{l}\text { Number } \\
\text { of inhabit- } \\
\text { ants }\end{array}$ & $\begin{array}{l}\text { Number } \\
\text { of munici- } \\
\text { palities }\end{array}$ & $\begin{array}{l}\text { Number } \\
\text { of inhabit- } \\
\text { ants }\end{array}$ & $\begin{array}{l}\text { Number } \\
\text { of munici- } \\
\text { palities }\end{array}$ & $\begin{array}{l}\text { Number } \\
\text { of inhabit- } \\
\text { ants }\end{array}$ & $\begin{array}{l}\text { Number } \\
\text { of munici- } \\
\text { palities }\end{array}$ \\
\hline $1-199$ & 6239 & 56 & 3843 & 34 & 4514 & 34 & 31212 & 241 \\
\hline $200-499$ & 57636 & 173 & 26891 & 82 & 30735 & 88 & 160818 & 461 \\
\hline $500-999$ & 129565 & 180 & 69417 & 97 & 50927 & 72 & 305869 & 436 \\
\hline $1000-1999$ & 216236 & 157 & 96631 & 69 & 79301 & 54 & 375393 & 267 \\
\hline $2000-4999$ & 205128 & 74 & 100110 & 31 & 79687 & 25 & 358382 & 123 \\
\hline $5000-9999$ & 142216 & 20 & 71583 & 10 & 16261 & 3 & 138563 & 20 \\
\hline $10000-19999$ & 197717 & 11 & 45753 & 3 & 69660 & 5 & 147444 & 13 \\
\hline $20000-49999$ & 131997 & 5 & 0 & 0 & 102529 & 3 & 615668 & 21 \\
\hline $50000+$ & 874264 & 5 & 0 & 0 & 147418 & 2 & 289137 & 4 \\
\hline SR & 1960998 & 681 & 414228 & 326 & 581032 & 286 & 2422486 & 1586 \\
\hline
\end{tabular}

Tab. 5 - The affiliation of municipalities and their inhabitants within individual size groups to clusters (share). Source: Own processing, data SGIDS \& SOSR, 2018 


\begin{tabular}{|c|c|c|c|c|c|c|c|c|}
\hline \multirow[t]{2}{*}{$\begin{array}{l}\text { Size type of } \\
\text { municipality }\end{array}$} & \multicolumn{2}{|l|}{ Cluster 1} & \multicolumn{2}{|c|}{$\begin{array}{l}\text { Lean toward to } \\
\text { cluster } 1\end{array}$} & \multicolumn{2}{|c|}{$\begin{array}{l}\text { Lean toward to } \\
\text { cluster } 2\end{array}$} & \multicolumn{2}{|l|}{ Cluster 2} \\
\hline & $\begin{array}{l}\text { Number } \\
\text { of inhab- } \\
\text { itants }\end{array}$ & $\begin{array}{l}\text { Number } \\
\text { of mu- } \\
\text { nicipali- } \\
\text { ties }\end{array}$ & $\begin{array}{l}\text { Number } \\
\text { of inhab- } \\
\text { itants }\end{array}$ & $\begin{array}{l}\text { Number } \\
\text { of mu- } \\
\text { nicipali- } \\
\text { ties }\end{array}$ & $\begin{array}{l}\text { Number } \\
\text { of inhab- } \\
\text { itants }\end{array}$ & $\begin{array}{l}\text { Number } \\
\text { of mu- } \\
\text { nicipali- } \\
\text { ties }\end{array}$ & $\begin{array}{l}\text { Number } \\
\text { of inhab- } \\
\text { itants }\end{array}$ & $\begin{array}{l}\text { Number } \\
\text { of mu- } \\
\text { nicipali- } \\
\text { ties }\end{array}$ \\
\hline $1-199$ & $14 \%$ & $15 \%$ & $8 \%$ & $9 \%$ & $10 \%$ & $9 \%$ & $68 \%$ & $66 \%$ \\
\hline $200-499$ & $21 \%$ & $22 \%$ & $10 \%$ & $10 \%$ & $11 \%$ & $11 \%$ & $58 \%$ & $57 \%$ \\
\hline $500-999$ & $23 \%$ & $23 \%$ & $12 \%$ & $12 \%$ & $9 \%$ & $9 \%$ & $55 \%$ & $56 \%$ \\
\hline $1000-1999$ & $28 \%$ & $29 \%$ & $13 \%$ & $13 \%$ & $10 \%$ & $10 \%$ & $49 \%$ & $49 \%$ \\
\hline $2000-4999$ & $28 \%$ & $29 \%$ & $13 \%$ & $12 \%$ & $11 \%$ & $10 \%$ & $48 \%$ & $49 \%$ \\
\hline $5000-9999$ & $39 \%$ & $38 \%$ & $19 \%$ & $19 \%$ & $4 \%$ & $6 \%$ & $38 \%$ & $38 \%$ \\
\hline $10000-19999$ & $43 \%$ & $34 \%$ & $10 \%$ & $9 \%$ & $15 \%$ & $16 \%$ & $32 \%$ & $41 \%$ \\
\hline $20000-49999$ & $16 \%$ & $17 \%$ & $0 \%$ & $0 \%$ & $12 \%$ & $10 \%$ & $72 \%$ & $72 \%$ \\
\hline $50000+$ & $67 \%$ & $45 \%$ & $0 \%$ & $0 \%$ & $11 \%$ & $18 \%$ & $22 \%$ & $36 \%$ \\
\hline SR & $36 \%$ & $24 \%$ & $8 \%$ & $11 \%$ & $11 \%$ & $10 \%$ & $45 \%$ & $55 \%$ \\
\hline
\end{tabular}

The number of inhabitants in the first cluster is 1,960,998 in municipalities that lean toward the first cluster of 414,228 inhabitants. 2,422,486 inhabitants lived in municipalities that belong to the second cluster, while 581,032 inhabitants lived in the municipalities that lean toward the second cluster.

The value of the membership function in the first cluster shows a significant positive spatial autocorrelation. The Moran coefficient value is 0.1277 ( $\mathrm{P}$ value is 0.0001$)$. Hence it was interesting to know which municipalities are causing such an autocorrelation, especially those municipalities with a high value of membership function in the first cluster neighboring to municipalities, and also with a high value of membership function to the first cluster, labelled High-High on the map.

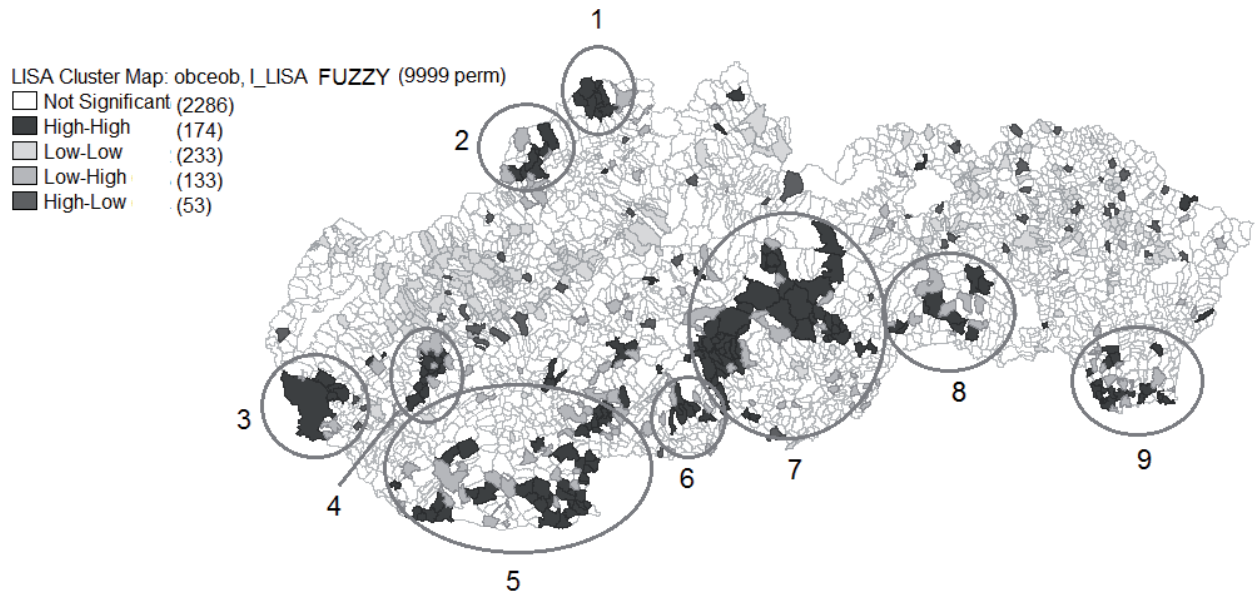

Fig. 7 - Local Moran cluster map for membership function to the first ('bad') cluster for all municipalities in the SR. Source: Own processing, data SGIDS \& SOSR, 2018 
Part 1 of the area of interest is part of the Kysuce Protected Landscape Area (Decree 68/1984), thus it may be assumed that the evaluated area is undisturbed from an environmental point of view. This zone, i.e. the Northern Slovakian districts of Námestovo, Čadca, Kysucké Nové Mesto and Bytča, is inhabited by those with the relatively worst mortality rates, a finding that was put forth by Bleha et al. (2014) in the latest demographic forecast for the districts of Slovakia up to 2035. A probable cause for this high mortality rate can be found in this area's history. More than a third of Kysuce Region inhabitants left the region to seek work, with some finding employment in neighboring Slovak regions, especially nearby Žilina, but the vast majority working in the mines and iron-mills of the Ostrava and Trrinec Region (Srajerova, 2009). The local labor market had failed to satisfy a growing demand in the mining, metallurgy and construction sectors, so labor resources were sought outside the area (Kovar \& Prokop, 1991). The use of asbestos in construction was typical in the building industry in those years.

In terms of energy sources for heating, wood was then typical in this area, but as explained above, this source has a negative environmental impact. The main air polluter in the area of interest 2 is the tire-producer Continental Matador Rubber. Interest area 3 has a high level of gas usage, with the main polluters consisting of vehicle exhaust emissions. This area of interest is formed by municipalities serviced by the overloaded access roads (no. 61, 502) to Bratislava and part of the D1 highway.

Interest areas 5, 6, and 9 are municipalities with high employment in agriculture, with a number of them featuring wine growing and production. Interest areas 7 and 8 are municipalities where iron, ore and copper had once been mined, waste products of which were slag and furnace excavations deposited in slag heaps. This material contained particles of reduced metals that did not pass into the alloy (Ladomersky et al., 2007). The degree of processing necessary in these areas led to the waste products being enriched by other substances which were alien to the original rock environment. Hutch and percolating water from dumps carry metals in sulfide or oxide form that have merely mechanically softened and have settled near the source. Primarily Fe, Mn, $\mathrm{Cu}, \mathrm{Al}$ and $\mathrm{Sb}$ as solutions and colloids are carried the furthest by the surface water.

The identified areas of interest in Figure 7 roughly correspond to the map "The burden of environmental compartments in districts of Slovakia by stress factors" introduced by Spacilova \& Izakovicova (2008). These authors evaluated and classified districts of the SR into categories according to factors that negatively affect ecological stability and individual natural resources, i.e. the 'stress factors' defined by Izakovicova \& Moyzeova (2003).

Following the mining and processing of ore, many of the municipalities' main employment is timber harvesting from surrounding forests, in which cases wood is used as an energy source for heating in these areas.

From the perspective if the European Union, air quality in Slovakia is over-polluted, with the problem mainly being the fine dust particles in the atmosphere. In 2006 and 2007, Slovakia was the worst among neighboring countries in terms of urban population exposure to air pollution by particulate matter. While Poland has held the unwelcome distinction of being the very worst in this parameter since 2008, urban population exposure to air pollution by particulate matter in the SR remains much higher than the EU average. 


\section{CONCLUSIONS}

EU policies and legislation in the field of the environment focus on the formation of an innovative competitive economy where biodiversity is protected, and health risks linked to the environment are minimized.

The aim of this paper was to identify the relationship between the pollution caused by heating and the health of population. The health status of the population was assessed using the potential years of life lost per 100,000 inhabitants. Data on the energy sources used for heating were taken from a survey of all dwellings in the Slovak Republic in the 2011 census of inhabitants, homes and apartments. To create clusters of similar municipalities in terms of the variables considered, we used the fuzzy cluster analysis for individual size-standard groups of municipalities.

We have identified a connection between the energy source used for heating (solid fuel and gas) and lost years of life (PYLL100) in the Slovak Republic at the municipal level. Dwellings heated with solid fuel in municipalities of up to 10,000 inhabitants are likely to be the largest air polluters. Extremely high values of PYLL100 in municipalities of the size type 1-199 are obviously due to a small number of laws regulating energy sources. The map view of the fuzzy cluster analysis results confirmed the division of the Slovak Republic into two regions - the north, which showed more favorable results, and the south, which showed negative findings. The membership function values of the first cluster indicate a significant positive spatial autocorrelation as measured by the Moran's coefficient.

In case of municipalities with a population over 10,000, the main polluter is road transport, i.e. current traffic capacities are insufficient, i.e. with slow-moving vehicles and traffic jams. Another delineation comprises municipalities featuring the stemmed mining of mineral resources. No affected area was significantly associated with emissions from industrial activities.

\section{Acknowledgments:}

This paper was supported by the Slovak Research and Development Agency under grants VEGA No. 1/0604/18 Economic Aspects of Sustainable Construction within intelligent city structures.

\section{References}

1. Adlong, W., \& Dietsch, E. (2015). Environmental education and the health professions: framing climate change as a health issue. Environmental Education Research, 21 (5), 687-709.

2. Alvarez, R. A., Pacala, S. W., Winebrake, J. J., Chameides, W. L., \& Hamburg, S. P. (2012). Greater focus needed on methane leakage from natural gas infrastructure. Proceedings of the National Academy of Sciences of USA. 109 (17), 6435-6440.

3. Androniceanu A., \& Drăgulănescu I. V. (2016). Survey on the buyers’ eco-responsibility and the urban white pollution. Environmental Engineering and Management Journal, February 2016, 15 (2), 481-487.

4. Androniceanu, A., \& Popescu, C. R. (2017). An inclusive model for an effective development of the renewable energies public sector. Administraie i Management Public, (28), 81-96.

5. ArcGIS Pro (2018). How Cluster and Outlier Analysis (Anselin Local Moran’s I) Works. 
6. Atilla -Tóth, A. (2016). The Impact of the Hotel Industry on the Competitiveness of Tourism Destinations in Hungary. Journal of Competitiveness, 8 (4), 85-104. https://doi. org/10.7441/joc.2016.04.06

7. Bleha, B., Šprocha, B., \& Vaňo, B., (2014). Demographic forecast of the districts of Slovakia up to 2035 in the context of the detection of geographical inequality and convergence. Acta Geographica Universitatis Comenianae, 58 (1), 11-44.

8. Borrego, C., Lopes, M., Valente, J., Tchepel, O., Miranda, A. I., \& Ferreira, J. (2008). The role of PM10 in air quality and exposure in urban area. WIT Transactions on Ecolog $y$ and the Environment, 116 (1), 511-520.

9. Brożyna J., Mentel G., \& Szetela B. (2016). Infl uence of double seasonality on economic forecasts on the example of energy demand. Journal of International Studies, 9 (3), 9-20. https://doi.org/10.14254/2071-8330.2016/9-3/1

10. Carrión-Flores, C. E., \& Innes, R. (2010). Environmental innovation and environmental performance. Journal of Environmental Economics and Management, 59 (1), 27-42.

11. Chun, Y., \& Griffith, D. A. (2013). Spatial statistics and geostatistics: theory and applications for geographic information science and technology. 1 edition, Publisher: SAGE Publications Ltd, pp. 200.

12. Cooper, J. A. (1980). Environmental impact of residential wood combustion emissions and its implications. Journal of the Air Pollution Control Association, 30 (8), 855-861.

13. Dančova, L. (2018). Vystavenie detí znečistenému vonkajšiemu ovzdušiu (PM10 a PM2,5). ENHIS. Available online: http://www.uvzsr.sk/docs/info/zp/factsheet_respiracne_ ochorenia.pdf

14. Dechezleprêtre, A., \& Sato, M. (2017). The impacts of environmental regulations on competitiveness. Review of Environmental Economics and Policy, 11 (2), 183-206.

15. Decree No. 68/1984 Coll., Decree of the Ministry of Culture of the Slovak Socialist Republic declaring the Kysuce Protected Landscape Area as amended by Act No. 287/1994 Coll.

16. European Commission (2018). Extern-E - External Costs of Energy. Available online: http://www.externe.info/externe_d7/ (accessed on 10 February 2018).

17. Eurostat (2018). Air pollution statistics - emission inventories. Available online: http:// ec.europa.eu/eurostat/statistics-explained/index.php/Air_pollution_statistics_-_emission_ inventories.

18. Finkelman, R. B., \& Gross, P. M. (1999). The types of data needed for assessing the environmental and human health impacts of coal. International Journal of Coal Geology, 40 (2-3), 91-101.

19. Frantal, B., \& Novakova, E. (2014). A curse of coal? Exploring unintended regional consequences of coal energy in the Czech Republic. Moravian Geographical Reports, 22 (2), $55-65$.

20. Frasca, D., Marcoccia, M., Tofful, L., Simonetti, G., Perrino, C., \& Canepari, S. (2018). Influence of advanced wood-fired appliances for residential heating on indoor air quality. Chemosphere, 211 (1), 62-71. https://doi.org/ 10.1016/j.chemosphere.2018.07.102 
21. Gardner, J. W., \& Sanborn, J. S. (1990). Years of potential life lost (YPLL)—what does it measure? Epidemiology, 1 (4), 322-329.

22. Hessel, P. A., Goldsmith, J. R., Wichmann, H., Wilson, W. E., \& Soskolne, C. L. (1997). Particulate air pollution and health: Emerging issues and research needs related to the development of air quality standards. Canadian Respiratory Journal, 4 (6), 323-328.

23. Izakovicova, Z., \& Moyzeova, M. (2003). Determinants of the ecological stability of the territory of Slovakia. Bratislava: Institute of Sociology of SAS.

24. Jandacka, J., Vantuch, M., Lenhard, R., Kaduchova, K., \& Caja, A. (2015). Emisne ratazenie zivotneho prostredia (Emission load on environment). EDIS- Publisher of Zilina University, Slovakia, 100.

25. Kacprzyk, J., \& Piedrczyk, W. (2015). Springer Handbook of Computational Intelligence. Springer.

26. Kinney, P. L., Chillrud, S. N., \& Ramstrom, S. (2002). Exposures to multiple air toxics in New York City. Environmental Health Perspectives, 110 (4), 539-546.

27. Kolkova, A. (2018a). Indicators of Technical Analysis on the Basis of Moving Averages as Prognostic Methods in the Food Industry. Journal of Competitiveness, 10 (4), 102-119. https://doi.org/10.7441/joc.2018.04.07

28. Kolkova, A. (2018b). Technical indicators as a quantitative method of forecasting in the business economy. In: 9th International Scientific Conference Managing and Modelling of Financial Risks. Ostrava. 221-228.

29. Kovar, J., \& Prokop, R. (1991). Slovak population in the Ostrava industrial area. In: Ostrava. Contribution to the history and construction of Ostrava and Ostrava region. Ostrava: Sfinga.

30. Ladomersky, J., Hroncova, E., \& Nosal, E. (2007). The proposal uses the site of a coal mine after the activity. Proceedings of the symposium, Detva, 2007, 85-95.

31. Lindsay, G., Macmillan, A., \& Woodward, A. (2011). Moving urban trips from cars to bicycles: impact on health and emissions. Australian and New Zealand journal of public health, 35 (1), 54-60.

32. Maca, V., \& Melichar, J. (2016). The Health Costs of Revised Coal Mining Limits in Northern Bohemia. Energies, 9 (81), 1-20.

33. Marchetti, S., Longhin, E., Bengalli, R., Avino, P., Stabile, L., Buonanno, G., Colombo, A., Camatini, M., \& Mantecca, P. (2019). In vitro lung toxicity of indoor PM10 from a stove fueled with different biomasses. Science of the total environment, 649, 1422-1433. Available online: https://doi.org/10.1016/j.scitotenv.2018.08.249.

34. Marikina, M. A. (2018). The Impact of Ecological Regulations and Management on National Competitiveness in the Balkan States. Journal of Competitiveness, 10 (4), 120-135. https://doi.org/10.7441/joc.2018.04.08

35. Markandya, A., \& Wilkinson, P. (2007). Electricity generation and health. The Lancet. 370 (9591), 979-990.

36. Omelchuk, V. O. (2018). Peculiarities of housing market: dynamics of housing availability in Ukraine. Entrepreneurship and Sustainability Issues, 6 (2), 538-547. http://doi.org/10.9770/ jesi.2018.6.2(5) 
37. Paolotti, L., Martino, G., Marchini, A., \& Boggia, A. (2017). Economic and environmental assessment of agro-energy wood biomass supply chains. Biomass and bioenergy, 97 (1), $172-185$.

38. Plus, M. (2018). Vykurovanie drevom - áno, či nie? TechPark. Available online: (http:// www.techpark.sk/technika-11-2009/vykurovanie-drevom-ano-ci-nie.html)

39. Shupler, M., Balakrishnan, K., Ghosh, S., Thangavel, G., Stroud-Drinkwater, S., AdairRohani, H., \& Brauer, M. (2018). Global household air pollution database: Kitchen concentrations and personal exposures of particulate matter and carbon monoxide. Data in brief, 21 (1), 1292.

40. Spacilova, R., \& Izakovicova, Z. (2008). Environmental Situation as a Condition of the Slovak Regions Development. Zivotne prostredie, 42 (1), 15-20.

41. SPP (2018). Map of SPP distribution network. Available online: http://www.sppdistribucia.sk/sk_distribucna-siet/sk_mapa-distribucnej-siete.

42. Srajerova, O. (2009). Kysuce's Inhabitants in Ostrava Region after 1945 year. HistoricaReview in History and Related Sciences, 16 (1), 307-316.

43. State Geological Institute of Dionýz Štúr (2018). Potential years of life lost per 100,000 of the population. Available online: https://www.geology.sk/geohealth/wp-content/ uploads/2012/03/Indikator-19_PYLL100_data.pdf

44. The Statistical Office of the Slovak Republic (2013). The Population and Housing Census in 2011.

45. Volchik, V., Klimenko, L. \& Posukhova, O. (2018). Socio-economic sustainable development and the precariat: a case study of three Russian cities. Enterpreneurship and Sustainability Issues, 6 (1), 41 -428. http://doi.org/10.9770/jesi.2018.6.1(25)

46. Wherry, R. J. (2014). Contributions to correlational analysis. New York: Academic Press.

47. Wilkinson, P., Smith, K.R., Davies, M., Adair, H., Armstrong, B.G., Barrett, M., Bruce, N., Haines, A., Hamilton, I., Oreszczyn, T., Ridley, I., Tonne, C., \& Chalabi, Z. (2009). Public health benefits of strategies to reduce greenhouse-gas emissions: household energy. The Lancet, 374 (9705), 1917-1929.

48. Zhao, B., Zheng, H., Wang, S., Smith, K. R., Lu, X., Aunan, K., \& Fu, X. (2018). Change in household fuels dominates the decrease in PM2. 5 exposure and premature mortality in China in 2005-2015. Proceedings of the National Academy of Sciences, 115 (49), 12401-12406. 


\section{Contact information}

doc. Ing. Daniela Spirkova, PbD.

Slovak. University of Technology in Bratislava

Institute of Management

Bratislava, Slovak Republic

E-mail:daniela.spirkova@stuba.sk

doc. Ing. Jitka Kloudova, Ph.D.

University of Entrepreneurship and Law

Prague, Carech Republic

E-mail:jitka.kloudova@gmail.com

ORCID: 0000-0002-8582-2323

doc. Ing. Aleksandr Kljucnikov, PhD.

University of Entrepreneurship and Law

Prague, Czech Republic

E-mail:kliuchnikov@gmail.com

ORCID: 0000-0003-0350-2658

prof. RNDr. Beata Steblikova, CSc.

Pan-European University

Faculty of Economics and Entrepreneurship

Bratislava, Slovak Republic

E-mail:steblikovab2@gmail.com 